\title{
Determinants of Glycemic control among Diabetes Mellitus Patients in a Tertiary Clinic in Gaborone,
}

Botswana: findings and implications

Godfrey M. Rwegerera ${ }^{1,2}$, Anthony Masaka ${ }^{3}$, Yordanka Pina-Rivera ${ }^{1,2}$, Thato Moshomoํ․ Marea Gaenamong ${ }^{4}$, Brian Godman $5,6,7,8^{*}$, Taibat Aderonke Oyewo ${ }^{2}$, Amos Massele ${ }^{9}$, Dereje Habte ${ }^{10}$

${ }^{1}$ Department of Internal Medicine, University of Botswana, Gaborone, Botswana. Email: moshomotkl@gmail.com

2Department of Medicine, Princess Marina Hospital, Gaborone, Botswana. Email: grwege@gmail.com; yordankapr@yahoo.com; aderonkeo@yahoo.co.uk

${ }^{2}$ Department of Public Health Management, Botho University, Gaborone, Botswana. Email; Anthony.masaka@bothouniversity.ac.bw

${ }^{4}$ Department of Emergency Medicine, Princess Marina Hospital, Gaborone, Botswana. Email: mareagaenamong@gmail.com

${ }^{5}$ Strathclyde Institute of Pharmacy and Biomedical Sciences, Strathclyde University, Glasgow, United Kingdom. Email; Brian.Godman@ki.se

${ }^{6}$ Division of Clinical Pharmacology, Karolinska Institutet, Stockholm, Sweden. Email: Brian.Godman@ki.se

${ }^{7}$ Health Economics Centre, University of Liverpool Management School, Liverpool, UK. Email:

Brian.Godman@liverpool.ac.uk

${ }^{8}$ Department of Public Health and Management, School of Pharmacy, Sefako Makgatho Health Sciences University, Pretoria, South Africa

${ }^{9}$ Department of Biomedical Sciences, University of Botswana, Gaborone, Botswana Email: masselea@mopipi.ub.bw

${ }^{10}$ Consultant Public Health Specialist, Addis Ababa, Ethiopia. Email: derejehabte@yahoo.com

*Author for correspondence: Brian Godman, Strathclyde Institute of Pharmacy and Biomedical Sciences, University of Strathclyde, Glasgow G4 ORE, United Kingdom. Email: brian.godman@strath.ac.uk. Telephone: 0141548 3825. Fax: 01415522562 and Division of Clinical Pharmacology, Karolinska Institute, Karolinska University Hospital Huddinge, SE-141 86, Stockholm, Sweden. Email: Brian.Godman@ki.se. Telephone + 46 8 58581068. Fax + 46859581070

(Accepted for publication in Hospital Practice - please keep CONFIDENTIAL)

\section{Abstract:}

Background and aims: Glycemic control among patients with diabetes mellitus is associated with a marked reduction of both macrovascular and microvascular complications; however, glycemic control remains an elusive goal worldwide. The aim of this study was to determine factors associated with glycemic control among patients attending a tertiary clinic in Botswana as limited information to date. Methods: Cross-sectional study in a tertiary clinic in Gaborone, Botswana. Patients were recruited between $21^{\text {st }}$ July 2015 and $21^{\text {st }}$ September 2015. The majority of the randomly recruited patients (368/380 - 96.8\%) had documentation of glycemic control $(\mathrm{HbA} 1 \mathrm{c})$ within three months of study recruitment and were subsequently included in the analysis. Glycemic control was categorized as desirable, suboptimal and poor if $\mathrm{HbA} 1 \mathrm{c}$ was $<7 \%, 7-9 \%$ and $>9 \%$ respectively. Data was analyzed using SPSS for descriptive statistics including both bivariate and multinomial logistic regression. Ap-value $<0.05$ was considered statistically significant. Results: The analyzed study population consisted of $258 / 368(70.1 \%)$ females with a mean age (SD) of $56.7 \pm 13.6$ years. Means (SDs) for diabetes duration and glycated haemoglobin were $7.2 \pm 7.1$ years and $7.97 \pm 2.02 \%$ respectively. Of the 368 patients, $136(36.95 \%)$ and $132 / 368(35.86 \%)$ had desirableand suboptimal glycemic control respectively. Older age, attending the clinic for more or equal to 3 years and not being on insulin were associated with both desirable and suboptimal glycemic control whereas duration of diabetes between 5-10 years was associated with poor glycemic control. Conclusions: The majority of patients had poor glycemic control. Older age and not being on insulin were associated with better glycemic control. The fact that patients on insulin had poor glycemic control calls for more research to determine timing of insulin initiations and dosing schedule factors as these will help toimprove overall glycaemic control in Botswana and elsewhere.

Key words: Diabetes mellitus, Glycosylated Hemoglobin A1c, HIV, Cross-Sectional Study, Antidiabetic Drugs, Insulin, Botswana

\section{Introduction}

Diabetes mellitus (DM) is a global pandemic, contributing appreciably to worldwide morbidity and mortality [1, 2]. This is particularly an issue in Africa where in 2010, 12.1 million people were estimated to be living with diabetes, and this is projected to increase to 23.9 million by 2030 [3]. In for instance in South Africa, $61 \%$ of the 
population are currently overweight, obese or severely obese [4], increasing future prevalence rates for DM unless addressed. According to 2015 International Diabetes Federation (IDF) data, 1 in 25 adults in Botswana currently have DM, which is growing. Overall, approximately 52,000 adults in Botswana currently have DM, with over $60 \%$ currently remaining undiagnosed. The overall prevalence of DM and impaired glucose tolerance (IGT) in Botswana in 2015 was estimated at $5.6 \%$ and $7.1 \%$ respectively [5].

Previous studies, including randomized controlled trials, have consistently shown that tight glucose control is associated with a reduction of both microvascular and macrovascular complications [1, 6-9]. In addition, improving patients' quality-of-life [10,11]. Despite this evidence, a high proportion of DM patients remain poorly controlled across countries [3,4,11-15]; consequently, patients are at risk of complications of DM. The challenges of failing to attain optimal glycemic control in clinical practice are complex [16]; including both patient and health-care provider related factors. Patient related factors include, but not limited to, medication adherence, fear of hypoglycemia, disease process and patients' attitudes; health-care factors include the number of hospital visits, types and number of antidiabetic medications being prescribed and health-provider attitudes [16, 17]. Previous studies have shown that several factors influence glycemic control. These include age, gender, race/ethnicity, education, marital status, body mass index, duration of diabetes, smoking, type and number of medications used, dietary habits and psychological aspects [16, 18, 19]. However, published studies have shown inconsistency, and in almost $50 \%$ of occasions the reason for poor glycemic control cannot be explained [20].

This study was conducted to determine sociodemographic and clinical factors associated with glycemic control among DM patients attending a tertiary clinic in Botswana. Limited information is currently available regarding possible factors that help determine glycemic control among patients with DM in Botswana. This is important as the prevalence of diabetes is growing across sub-Sahara Africa including Botswana [3,4,21,22]. We are aware that factors such as genetics, dietary patterns, and cultural backgrounds, may play a role in glycemic control. However, it is important to have local understanding to guide future studies and policies to improve glycemic control in Botswana, and ultimately reduce the extent of complications arising from DM. These findings may also be of interest to other sub-Saharan African countries as they try to improve the management of their patients with diabetes.

\section{Materials and Methods}

\subsection{Study design, population and data collection}

This was a cross-sectional study conducted among patients with Type 2 DM attending a tertiary clinic at Princess Marina Hospital (PMH) in Gaborone, Botswana. PMH is the leading tertiary public hospital in Botswana offering services to over 3000 diabetic patients, a number of whom will also have HIV and other comorbidities, which may impact on medication adherence if pill counts are appreciably increased [22]. The data used for analysis in this study emanates from two primary studies, which have previously been published. Full details of how patients were selected for this study, along with their sociodemographic and clinical variables, can be found elsewhere [11, 22].

Briefly, the clinic in this tertiary hospital provides services for patients with DM including physician consultations, health education, and eye and foot screening as well as issuing medicines, which are provided free-of-charge. On average 1,800 to 2,000 diabetic-patients visit the clinic monthly with 1,400 of these visitations including physician consultations. Previously, we showed that glycemic control was not associated with adherence to antidiabetic medication overall, except for a subgroup of HIV-positive patents. There was better adherence to antidiabetic medicines among HIV-positive patients compared with HIV-negative patients and those with unknown serostatus [22]. Consequently, we undertook this study to examine further the determinants of glycemic control among our study participants. For the purpose of this study, 368/380 (96.8\%) patients had recent results (within 3 months) for glycosylated haemoglobin (HbA1c); hence they were included in this analysis. Glycemic control (HbA1c) was categorized into three categories as follows: desirable $(<7 \%)$, suboptimal (7-9\%) and poor ( $\geq 9 \%$ ) [23] Body mass index (BMI) was calculated as a ratio of weight in $\mathrm{kg}$ divided by height in $\mathrm{m}^{2}$ and categorized as underweight $(<18.5)$, normal weight $(18.5-24.9)$, overweight (2529.9 ) and obese ( $\geq 30$ ). BMI categorization was done according to World Health Organization (WHO) [24]. Results of patients' haemoglobin $(\mathrm{Hb})$ were also extracted from the hospital Intergrated Patient Management System (IPMS) and categories of anaemia were made according to WHO as follows; $\mathrm{Hb}<13 \mathrm{~g} / \mathrm{dl}$ for men and $\mathrm{Hb}<12 \mathrm{~g} / \mathrm{dl}$ for women. Sub-categories of anemia were mild (11-11.9g/dl for women and 11-12.9 for men); moderate $(8-10.9 \mathrm{~g} / \mathrm{dl})$ and severe $(<8 \mathrm{~g} / \mathrm{dl})[25]$.

At our clinic,during their first visit patients are screened for autoimmune and pancreatic antibodies. Patients categorized as type 1 DM had either of the two types of antibodies detected. Whilst the majority of patients' antibodies results could not be traced for verification, we relied largerly on a diagnosis of DM as type 1 or 2 based on the diagnosis documented in the patients' folders. 
Ethical clearance was obtained from Institutional Review Boards of Princess Marina Hospital, University of Botswana and the Ministry of Health, Botswana.

\subsection{Statistical analysis}

Descriptive statistics were used to summarize patients' sociodemographic and clinical characteristics. Statistical analysis was carried out using Statistical Package for Social Sciences (SPSS, version 22). Chi-square test was used to assess statistical significance of the difference in the percentages of good glycemic control according to independent categorical and continuous variables. One-way analysis of variance (ANOVA) was applied for comparisons of mean serum creatinine between three glycemic categories goups. Multinomial logistic regression models were performed to determine factors associated with glycemic control. All the independent variables studied were analyzed using both bivariate and multinomial logistic regression so as to ensure the impact of missing data, unbalanced sample size and large intragroup variation is countered as explained by Simpson's paradox [26]. A 95\% confidence interval and $p$ value less than 0.05 was considered statistically significant.

\section{Results}

\subsection{Sociodemographic and clinical characteristics}

Out of the 368 patients, $258(70.1 \%)$ were female; mean age of study population was (SD) of $56.7 \pm 13.6$ years with $71.4 \%$ aged more or equal to 51 years. Means (SDs) for diabetes duration and glycated haemoglobin were $7.2 \pm 7.1$ years and $7.97 \pm 2.02 \%$ respectively. Approximately $40 \%$ of patients were illiterate with either no formal education or not completed primary school. The majority of the study population who had complete data for body mass index were either overweight or obese, consisting of 256/326 (78.5\%) patients. Moderate anemia was found in 29/368 (7.9\%) of the study participants (Table 1). Other sociodemographic and clinical characteristics are summarized in Table 1.

Insert Table 1

\subsection{Determinants of Glycemic control}

Of the 368 patients, only $136(36.9 \%)$ had desirable glycemic control. Univariate analysis showed that older age groups were associated with desirable glycemic control in that $35.8 \%$ and $51.5 \%$ of patients aged $51-65$ and $\geq$ 66 years respectively had desirable glycemic control compared to $16.7 \%$ and $28 \%$ of those aged $21-35$ and 36 50 years. In addition, $42.5 \%$ of patients with a duration of diabetes $<5$ years had desirable glycemic control compared to $31.2 \%$ of those with a duration of diabetes $>10$ years . Bivariate analysis revealed that older age, duration of diabetes of 5-10 years, duration of attending the clinic of $\geq 3$ years and monotherapy with oral hypoglycemic agents were associated with better glycemic control (Table 2). Other sociodemographic and clinical variables did not have statistical significance (Table 2).

Insert Table 2

\subsection{Multinomial regression analysis of factors associated with good glycemic control}

In mind of the Simpson effect whereby some variables with either missing data in our study such as unknown HIV positive patients might have resulted into wrong bivariate analysis findings, we decided to run all the studied variables into a multinomial analysis model regardless of their significance in bivariate analysis. The type of diabetes caused some unexpected singularities in the hessian matrix which could give invalid estimates, hence it was removed from the final model. Older age, attending the clinic for more or equal to 3 years and not being on insulin were associated with both desirable and suboptimal glycemic control whereas the duration of diabetes between 5-10 years was associated with poor glycemic control. Of note is the fact that glycemic control was not associated with the degree of anaemia.(Table 3).

Insert Table 3

\subsection{Association between serum creatinine and glycemic control}

There was no significant difference in renal function using mean serum creatine between the three categories of glycemic control $(p$-value $=0.645)($ Table 4$)$

Insert Table 4

\section{Discussion}

This study revealed that majority of our patients $(60.1 \%)$ had poor glycemic control. This high proportion of patients with poor glycemic control is similar though to the findings from other previous studies [27-31]. 
It is paramount to point out that the use of glycosylated haemoglobin ( $\mathrm{HbA} 1 \mathrm{c})$ to assess diabetes control should be interpreted with caution. $\mathrm{HbA} 1 \mathrm{c}$ is recognized as a relaiable marker of excess glycation and it is an intergrator of both fasting and post-prandial glycemic disorders [32, 33]. On the other hand, results of HbA1c can be affected by several different factors including but not limited to genetic, physiological, haematological and illness-related factors such as haemolyticanaemia, hemoglobinopathies, acute and chronic blood loss, chronic malaria, pregnancy and serum creatinine [34-36]. Hence, variations in measurents of $\mathrm{HbA} 1 \mathrm{c}$ are expected especially in different ethinic and racial populations [37, 38], calling upon for the need for validation. Care of patients with DM in Botswana has adopted Society of Endocrinolofy and Metabolism of South Africa (SEMDSA) guidelines [39] which recommends $\mathrm{HbA1c}$ for glycemic control. On the other hand, a recent study in Botswana looking at diagnostic accuracy found a modest relationship between $\mathrm{HbA} 1 \mathrm{c}$ and fasting blood glucose [40].

Despite the lack of local research on some conditions that could affect HbA1c levels in our settings, clinical evidence indicates that malaria is non-endemic in the southern part of Botswana where this study was conducted; furthermore haemogloninapthies such as sickle cell disease are very rare.

The degree of anaemia and serum creatininine have been found to affect measurements of glycosylated haemoglobin in contrasting ways in previous studies [36, 41-43]. However, when we analyzed these two variables we did not find any association with $\mathrm{HbA} 1 \mathrm{c}$.

It has been consistently shown that a longer the duration of diabetes is associated with progressive impairment of insulin secretion [8] as well as poorer adherence to antidiabetic medications; hence poor glycemic control $[18,19,31,44-47]$. However, our study showed contrasting findings whereby the duration of diabetes of 5-10 years was associated with both desirable and suboptimal glycemic control compared to duration of diabetes of $>10$ years. One possible explanation is that majority of our patients were diagnosed late (less than 5 years prior to the interval date) and they already had presented with complications [22]. We will be following this up in future research projects.

Previous studies have shown that old age is associated with better glycemic control [48-52]; probably because old people tend to have more complications with their symptoms [52] which could enhance adherence to antidiabetic medications. Our study also found consistent findings whereby older people had better glycemic control.

The increased number of medicines a patient is currently taking has also been associated with poor glycemic control. This may be a reflection of the efforts of physicians to increase the type and dosage of medicines used to counter poor glycemic control and associated complications [27, 53,54], with pill burden known to adversely affect adherence $[22,53,55]$. However, our study revealed no significant association between the number of oral hypoglycemic agents in use and glycemic control. The reasons for this might be multifactorial. We paroxically found that patients whose treatment regimen did not include insulin regimen had a significant chance of having either desirable or suboptimal glycemic control. The possible explanation for this are factors such as the timing of initiation of insulin and insulin regimen schedules. This phenomenon has also been reported elsewhere [56, 57 ], and we will again be looking at this further in future research projects.

The combination of other factors such asa reluctance among physicians to initiate insulin early and wait until the disease has worsened, or a combination of other factors including a lack of physical exercise and diet modifications, may have contributed to overall poor glycemic control in our study particpants. Having said this, the contribution of physical exercise and diet to glycemic control in our patient population was not evaluated, which will need further exploration in the future.

Our study also revealed no significant association between glycemic control and other variables including gender, level of education, marital status, and blood pressure control. This is similar though to the findings from previously published studies [58, 59].

Higher body mass index (BMI) has been shown to be a predictor of poor glycemic control in previous studies $[51,60,61]$. However, this was in contrast to our study where BMI was not associated with glycemic control. A possible explanation for this is that our sample population consisted of an appreciably number of patients with higher BMls, with over $75 \%$ of patients already being either overweight or obese. This will again be looked at further given the extent of patients overweight or obese in our study population.

Our previous study showed that glycemic control was not associated with adherence to antidiabetic medication [22]. This underpins the fact that glycemic control may partly be affected by other self-management behaviors such as self-monitoring of glucose and self-care activities such as number of clinic visits which, as mentioned, we did not evaluateOur clinic also provide a range of other services including foot care, eye examination, and 
dietary couseling. The extent of adherence to such activities was not studied and they will also be the subject of future research.

According to Hartz et al, patients' understanding of diabetes and adherence to recommended behaviors was associated with better glycemic control compared to physiological factors [54]. However, this association was not studied in our population, and needs to be addressed to guide future policies alongside looking more closely at patients with diabetes mellitus This will also be studied in future research projects in this and others clinics across Botswana to provide additional guidance of possible measures to improve glycemic control in the future given current concerns.

\subsection{Study limitations}

It is imperative that our findings are interpreted on the background of several limitations. Firstly, this is a crosssectional study design and does not explain causality. Secondly, we did not study self-management behaviors and we know psychosocial variables impact on glycemic control, which have been found to affect glycemic control in previous studies.Lastly, we did not collect data on fasting and post-prandial to compare with $\mathrm{HbA} 1 \mathrm{c}$ levels. Despite these limitations, we believe our study findings are robust and offer insight for future targeted interventional studies in diabetes patients by providing epidemiological data and helping prioritize management decisions in situations where there are limited resources.

\section{Conclusions}

The majority of patients in our clinic in Botswana had poor glycemic control, similar to most published studies. Older age and not being on insulin were associated with better glycemic control. The fact that patients on insulin had poor glcycemic control calls for more research to determine the timing of insulin initiations and dosing schedule factors as these will help to better improve overall glycaemic control in patients with diabetes in Botswana and elsewhere.

\section{Conflict of interests}

All authors declare that they have no conflict of interests related to this work. There was no funding for this research.

\section{Acknowledgements}

We would like to acknowledge all the staff of Block 6 Reference clinic for their corporation and support in handling patients during the process of data collection.

\section{References:}

1. Koro CE, Bowlin SJ, Bourgeois N, Fedder DO. Glycemic control from 1988 to 2000 among US adults diagnosed with type2diabetes: A preliminary report. Diabetes Care. 2004; 27(1): 17-20.

2. International Diabetes Federation. (2017). Diabetes Atlas, (8th ed.). Brussels: International Diabetes Federation. Available at URL: http://www.diabetesatlas.org/resources/2017-atlas.html

3. Hall V, Thomsen RW, Henriksen O, Lohse N. Diabetes in Sub Saharan Africa 1999-2011: Epidemiology and public health implications. a systematic review. BMC public health. 2011;11:564

4. Baleta A, Mitchell F. Country in Focus: Diabetes and obesity in South Africa. The lancet Diabetes \& endocrinology. 2014;2(9):687-8

5. Botswana International Diabetes Federation Atlas (2015). Available at URL: https://www.idf.org/ournetwork/regions-members/africa/members/1-botswana.html.

6. Saadine JB, Engelgau MM, Beckles GL, Gregg EW, Thompson TJ, Venkat KM. A diabetes report card for the United States: Quality of care in the 1990's. Annals of Internal Medicine. 2002; 136: 565-74.

7. The Diabetes Control and Complications Trial Research Group. The effect of intensive treatment of diabetes on the development and progression of long-term complications in insulin-dependent diabetes mellitus. New England Journal of Medicine. 1993; 329: 977-86.

8. UK Prospective Diabetes Study (UKPDS) Group. Intensive blood glucose control with sulphanylureas or insulin compared with conventional treatment and risk of complications in patients with Type 2 diabetes. Lancet. 1998; 352: 837-53.

9. Middleton J. The effect of case management on glycemic control in patients with type 2 diabetes. The Case Manager. 2003; 14:43-47.

10. da Mata AR, Alvares J, Diniz LM, Ribeiro da Silva MR, Alvernaz dos Santos BR, Guerra Junior AA, et al. Quality of life of patients with Diabetes Mellitus Types 1 and 2 from a referal health centre in Minas Gerais, Brazil. Expert review of clinical pharmacology. 2016; 9(5):739-46 
11. Rwegerera GM, Moshomo T, Gaenamong M, Oyewo TA, Gollakota S, Piña-Rivera Y, et al. Health related quality of life and associated factors among patients with diabetes mellitus in Botswana. Alexandria Journal of Medicine. 2018; 54: 111-18. Available at URL: https://www.sciencedirect.com/science/article/pii/S209050681730091X

12. Karter AJ, Moffet HH, Liu J, Parker MM, Ahmed AT, Ferrara A, et al. Achieving good glycemic control: Initiation of new anti-hyperglycemic therapies in patient with Type 2 diabetes from the Kaiser Permanente Northern California diabetes registry. American Journal of Managed Care. 2005; 11: 262-70.

13. Marra LP, Araujo VE, Oliveira GC, Diniz LM, Guerra Junior AA, de Assis Acurcio F, et al. The clinical effectiveness of insulin glargine in patients with Type I diabetes in Brazil: findings and implications. Journal of comparative effectiveness research. 2017; 6(6): 519-27.

14. Iqbal Q, Bashir S, Iqbal J, Iftikhar S, Godman B. Assessment of medication adherence among type 2 diabetic patients in Quetta city, Pakistan. Postgraduate medicine. 2017;129(6):637-43

15. Aung WP, Htet AS, Bjertness E, Stigum H, Chongsuvivatwong V, Kjøllesdal MKR. Urban-rural differences in the prevalence of diabetes mellitus among 25-74 year-old adults of the Yangon Region, Myanmar: two cross-sectional studies. BMJ open. 2018;8(3):e020406

16. Wallace TM, Matthews DR. Poor glycemic control in Type 2 diabetes, conspiracy of disease, suboptimal therapy and attitude. Quarterly Journal of Medicine. 2000; 93: 369-74.

17. Rhee MK, Slocum W, Ziemer DC, Culler SD, Cook CB, El-Kebbi IM, et al. Patient adherence improves glycemic control. Diabetes Educator. 2005; 31: 240-50.

18. Khattab M, Khader YS, Al-Khawaldeh A, Ajlouni K. Factors associated with poor glycemic control among patients with type 2 diabetes. J Diabetes Complications. 2003; 24: 84-89.

19. Blaum CS, Velez L, Hiss RG, Halter JB. Characteristics related to poor glycemic control in NIDDM patients in community practice. Diabetes Care. 1997; 20(1):7-11.

20. Goudswaard AN, Stolk RP, Zuithoff P, Rutten GE. Patient characteristics do not predict poor glycaemic control in type 2 diabetes patients treated in primary care. Eur J Epidemiol. 2004, 19:541-45.

21. Meyer JC, Schellack N, Stokes J, Lancaster R, Zeeman H, Defty D, et al. Ongoing Initiatives to Improve the Quality and Efficiency of Medicine Use within the Public Healthcare System in South Africa; A Preliminary Study. Frontiers in pharmacology. 2017; 8:751.

22. Rwegerera GM, Moshomo T, Gaenamong M, Oyewo TA, Gollakota S, Mhimbira FA, et al. Antidiabetic Medication Adherence and Associated Factors among Patients in Botswana; implications for the future. Alexandria Journal of Medicine. 2018; 54: 103-109. Available at URL:

https://www.sciencedirect.com/science/article/pii/S2090506817300064

23. Gerstein HC, Swedberg K, Carlsson J, McMurray JJ, Michelson EL, Olofsson B, et al. The hemoglobin A1c level as a progressive risk factor for cardiovascular death, hospitalization for heart failure, or death in patients with chronic heart failure: an analysis of the Candesartan in Heart failure: Assessment of Reduction in Mortality and Morbidity (CHARM) program. Arch Intern Med. 2008; 168: 1699-1704.

24. World Health Organization. Physical status:the use and interpretation of anthropometry. 1995. Geneva. WHO Technical Report Series 854. ww.who.int/gho/ncd/risk_factors/bmi_text/en/ Last accessed on 02 ${ }^{\text {nd }}$ October 2018.

25. World Health Organization. Nutritional anaemias. Report of a WHO Scientific group.World Health Organ Tech Rep Ser.1968;405-5-37.

26. Lo SK, Li IT, Tsou TS, See L. Non-significant in univariate but significant in multivariate analysis: a discussion with examples. Changgeng Yi Xue Za Zhi. 1995; 18 (2): 95-101.

27. Fox KM, Gerber RA, Bolinder B, Chen J, Kumar S. Prevalence of inadequate glycemic control among patients with type 2 diabetes in the United Kingdom General Practice Research Database: a series of retrospective analyses of data from 1998 through 2002. Clin Ther. 2006; 28(3):388-95.

28. Kassahun $\mathrm{T}$, Eshetie $\mathrm{T}$, Gesesew $\mathrm{H}$. Factors associated with glycemic control among adult patients with type 2 diabetes mellitus: a cross-sectional survey in Ethiopia. BMC Research Notes. 2016; 9:78.

29. Gebrehiwot T, Jemal H, Dawit T. Non-adherence and Associated Factors among type 2 diabetic patients at Jimma University Specialized Hospital, Southwest Ethiopia. J Med Sci. 2013; 13:578-84.

30. Hailu E, Mariam WH, Belachew T, Birhanu Z. Self-care practice and glycaemic control amongst adults with diabetes at the Jimma University Specialized Hospital in south-west Ethiopia: A cross-sectional study. Afr J Prim Health Care Fam Med. 2012; 4(1):311-6.

31. Benoit SR, Fleming R, Philis-Tsimikas A, Ji M. Predictors of glycemic control among patients with Type 2 diabetes: a longitudinal study. BMC Public Health JT - BMC Public Health. 2005; 5: 36.

32. Executive Summary. Standards of medical care in diabetes-2009. Diabetes Care. 2009; 32: S6-S12.

33. Inzucchi SE, Bergenstal RM, Buse JB, Diamant M, Ferrannini E, Nauck M, et al. Management of Hyperglycaemia in Type 2 Diabetes: A Patient-Centered Approach Position Statement of the American Diabetes Association (ADA) and the European Association for the Study of Diabetes (EASD). Diabetes Care. 2012; 35(6): 1364-1379.

34. Bansal P, Nayak P, Sharma BD. Understanding glycosylated haemoglobin . JIACM 2014; 15(3-4): $220-1$. 
35. Unnikrishnan R, Anjana RM, Mohan V. Drugs affecting HbA1c levels. Indian J Endocr Metab 2012;16:52831.

36. Farasat T, Sharif S, Naz S, Fazal S. Significant association of serum creatinine with HbA1C in impaired glucose tolerant Pakistani subjects. Pak J Med Sci. 2015; 31(4):991-94. doi:10.12669/pjms.314.7063.

37. Herman $\mathrm{WH}$,Cohen RM. Racial and ethnic differences in the relationship betweenHbA1c and blood glucose:implications for the diagnosis of diabetes. J Clin Endocrinol Metab. 2012 Apr;97(4):1067-72.

38. Venkataraman K, Kao SL, Thai AC, Salim A, Lee JJ, Heng D, et al. Ethnicity modifies the relation between fasting plasma glucose and HbA1c in Indians, Malays and Chinese. Diabet Med. 2012 Jul;29(7):911-7.

39. SEMDSA 2017 Guidelines for the Management of Type 2 diabetes mellitus SEMDSA Type 2 Diabetes Guidelines Expert Committee. JEMDSA 2017; 22(1)(Supplement 1): S1-S196.

40. Omech B, Tshikuka J-G, Amone-P'Olak K, Mwita J, Tsima B, Nkomazana O. The utilization of HbA1c test in the screening and diagnosis of type 2 diabetes mellitus: An outpatient clinics survey in Botswana. Journal of Diabetes and Endocrinology,2007; $8: 1-8$.

41. Sakthidasan S, Hemachandrika C, Suthakaran C. Relationship between the levels of glycosylated haemoglobin red cell width and haemoglobin levels in patients with type 2 diabetes mellitus. Indian Journal of Basic and Applied Medical Research. 2017; 6 (2): 645-651.

42. Christy AL, Manjrekar PA, Babu RP, Hegde A, Rukmini MS. Influence of iron deficiency anaemia on hemoglobin A1c levels in diabetic individuals with controlled plasma glucose levels. Iran Biomed J. 2014;18(2):88-93.

43. Sinha N, Mishra TK, Singh T, Gupta N. Effect of iron deficiency anaemia on hemoglobin A1c levels. Ann Lab Med. 2012; 32(1):17-22.

44. Bruce DG, Davis WA, Davis TM. Glycemic control in older subjects with type 2 diabetes mellitus in the Fremantle Diabetes Study. J Am Geriatr Soc. 2000; 48(11):1449-53.

45. Chiu C-J, Wray LA. Factors predicting glycemic control in middle-aged and older adults with type 2 diabetes. Prev Chronic Dis. 2010; 7(1): A08.

46. Valle T, Koivisto A, Reunanen A, Kangas T, Rissanen A. Glycemic control in patients with diabetes in Finland. Diabetes Care. 1999; 22 (4), 575-79.

47. Verma M, Paneri S, Badi P, Raman, G. Effect of increasing duration of diabetes mellitus Type 2 on glycated hemoglobin and insulin sensitivity. Indian Journal of Clinical Biochemistry. 2006; 21(1): 142-46.

48. Rothenbacher D, Ruter G, Saam S, Brenner H. Younger patients with Type 2 diabetes need better glycemic control: Results of a community-based study describing factors associated with a high $\mathrm{HbA} 1 \mathrm{c}$ value. British Journal of General Practice. 2003; 53: 389-91.

49. Juarez DT, Sentell T, Tokumaru S, Goo R, Davis JW, Mau MM. Factors Associated With Poor Glycemic Control or Wide Glycemic Variability Among Diabetes Patients in Hawaii, 2006-2009. Prev Chronic Dis. 2012; 9:120065.

50. Davidson MB, Schriger DL. Effect of age and race/ethnicity on HbA1c levels in people without known diabetes mellitus: implications for the diagnosis of diabetes. Diabetes Res Clin Pract. 2010; 87:415-21.

51. Gulliford MC, Ukoumunne OC. Determinants of glycated haemoglobin in the general population: associations with diet, alcohol and cigarette smoking. Eur J Clin Nutr. 2001; 55:615-23.

52. Chan WB, Chan JC, Chow CC, Yeung VT, So WY, Li JK, et al. Glycaemic control in type 2 diabetes: the impact of body weight, beta-cell function and patient education. QJM. 2000, 93:183 190.

53. Rwegerera GM. Adherence to anti-diabetic drugs among patients with Type 2 diabetes mellitus at Muhimbili National Hospital, Dar es Salaam, Tanzania-a cross-sectional study. Pan African Medical Journal 2014; 17 (252).

54. Hartz A, Kent S, James P, Xu Y, Kelly M, Daly J. Factors that influence improvement for patients with poorly controlled type 2 diabetes. Diabetes Res Clin Pract. 2006; 74:227-32.

55. Vrijens B, Antoniou S, Burnier M, de la Sierra A, Volpe M. Current Situation of Medication Adherence in Hypertension. Frontiers in pharmacology. 2017; 8:100.

56. Adeniyi OV, Yogeswaran P, Longo-Mbenza B, Ter Goon D, Ajayi Al. Cross-sectional study of patients with type 2 diabetes in OR Tambo district, South Africa. BMJ Open. 2016;6:e010875. doi:10.1136/bmjopen2015- 010875.

57. Kumar P. Kumar \& Clark's Clinical Medicine. International Edition ed. 2009.

58. Ghazanfari Z, Niknami S, Ghofranifour F, Larijani B, Agha-Alinejad H, Montazeri A. Determinants of glycemic control in female diabetic patients: a study from Iran. Lipids in Health and Disease. 2010; 9:83.

59. Woldu MA, Wami CD, Lenjisa JL, Tegegne GT, Tesafye G, Dinsa H. Factors Associated with Poor Glycemic Control among Patients with Type 2 Diabetes Mellitus in Ambo Hospital, Ambo; Ethiopia. Endocrinol Metab Synd. 2014; 3 (4).

60. Zhang SL, Chen ZC, Yan L, Chen LH, Cheng H, Ji LN. Determinants for inadequate glycaemic control in Chinese patients with mild-to-moderate type 2 diabetes on oral antidiabetic drugs alone. Chinese Med J (Engl). 2011; 124: 2461-68. 
61. Brown JB, Nichols GA, Perry A. The burden of treatment failure in type 2 diabetes. Diabetes Care. 2004; 27: 1535-40. 
Table 1: Sociodemographic and clinical characteristics of study participants

\begin{tabular}{|c|c|c|c|c|}
\hline \multirow[b]{2}{*}{ Variables } & \multicolumn{3}{|c|}{ Glycemic control } & \multirow[b]{2}{*}{ Total } \\
\hline & $\begin{array}{l}\text { Desirable } \\
(<7 \%)\end{array}$ & $\begin{array}{l}\text { Suboptimal } \\
(7-9 \%)\end{array}$ & $\begin{array}{l}\text { Poor } \\
(>9 \%)\end{array}$ & \\
\hline \multicolumn{5}{|l|}{ Gender } \\
\hline Male & $33(30.0 \%)$ & $39(35.5 \%)$ & $38(34.5 \%)$ & 110 \\
\hline Female & $103(39.9 \%)$ & $93(36.0 \%)$ & $62(24.0 \%)$ & 258 \\
\hline \multicolumn{5}{|l|}{ Age in years } \\
\hline $21-35$ & $5(16.7 \%)$ & $5(16.7 \%)$ & $20(66.7 \%)$ & 30 \\
\hline $36-50$ & $21(28.0 \%)$ & $28(37.3 \%)$ & $26(34.7 \%)$ & 75 \\
\hline $51-65$ & $58(35.8 \%)$ & $67(41.4 \%)$ & $37(22.8 \%)$ & 162 \\
\hline$\geq 66$ & $52(51.5 \%)$ & $32(31.7 \%)$ & $49(48.5 \%)$ & 101 \\
\hline \multicolumn{5}{|l|}{ Highest level of education } \\
\hline No formal education & $30(43.5 \%)$ & $23(33.3 \%)$ & $16(23.2 \%)$ & 69 \\
\hline Less than primary school & $31(40.3 \%)$ & $24(31.2 \%)$ & $22(28.6 \%)$ & 77 \\
\hline Primary school completed & $36(35.6 \%)$ & $44(43.6 \%)$ & $21(20.8 \%)$ & 101 \\
\hline Secondary school completed & $23(31.1 \%)$ & $27(36.5 \%)$ & $24(32.4 \%)$ & 74 \\
\hline College/University completed & $12(29.3 \%)$ & $13(31.7 \%)$ & $16(39.0 \%)$ & 41 \\
\hline Postgraduate degree & $4(66.7 \%)$ & $1(16.7 \%)$ & $1(16.7 \%)$ & 6 \\
\hline \multicolumn{5}{|l|}{ Marital status } \\
\hline Never married & $32(32.7 \%)$ & $31(31.6 \%)$ & $35(35.7 \%)$ & 98 \\
\hline Currently married & $62(40.8 \%)$ & $49(32.2 \%)$ & $41(27.0 \%)$ & 152 \\
\hline Separated & $0(0 \%)$ & $2(100 \%)$ & $0(0 \%)$ & 2 \\
\hline Divorced & $2(15.4 \%)$ & $7(53.8 \%)$ & $4(30.8 \%)$ & 13 \\
\hline Widowed & $34(45.3 \%)$ & $31(41.3 \%)$ & $10(13.3 \%)$ & 75 \\
\hline Cohabiting & $6(21.4 \%)$ & $12(42.9 \%)$ & $10(35.7 \%)$ & 28 \\
\hline \multicolumn{5}{|l|}{$\mathrm{BMI}$ in $\mathrm{kg} / \mathrm{m}^{2}$} \\
\hline Underweight & $2(40.0 \%)$ & $1(20.0 \%)$ & $2(40.0 \%)$ & 5 \\
\hline Normal weight ( & $24(36.9 \%)$ & $18(27.7 \%)$ & $23(35.4 \%)$ & 65 \\
\hline Overweight & $41(43.6 \%)$ & $31(33.0 \%)$ & $22(23.4 \%)$ & 94 \\
\hline Obese & $59(36.4 \%)$ & $66(40.7 \%)$ & $37(22.8 \%)$ & 162 \\
\hline Missing & & & & 42 \\
\hline \multicolumn{5}{|l|}{ Type of diabetes mellitus } \\
\hline Type 1 & $2(8.7 \%)$ & $5(21.7 \%)$ & $16(69.6 \%)$ & 23 \\
\hline Type 2 & $134(38.8 \%)$ & $127(36.8 \%)$ & $84(24.3 \%)$ & 345 \\
\hline \multicolumn{5}{|l|}{ Duration of Diabetes in years } \\
\hline$<5$ & $74(42.5 \%)$ & $58(33.3 \%)$ & $42(24.1 \%)$ & 174 \\
\hline $5-10$ & $25(29.8 \%)$ & $29(34.5 \%)$ & $30(35.7 \%)$ & 84 \\
\hline$>10$ & $29(31.2 \%)$ & $37(39.8 \%)$ & $27(29.0 \%)$ & 93 \\
\hline Missing & & & & 17 \\
\hline \multicolumn{5}{|l|}{ Duration of attending block 6} \\
\hline clinic & $75(40.1 \%)$ & $55(29.4 \%)$ & $57(30.5 \%)$ & 187 \\
\hline$<3$ years & $60(33.5 \%)$ & $76(42.5 \%)$ & $43(24.0 \%)$ & 179 \\
\hline$\geq 3$ years & & & & 2 \\
\hline \multicolumn{5}{|l|}{ Missing } \\
\hline \multicolumn{5}{|l|}{ Modality of treatment of diabetes } \\
\hline Diet & $3(75.0 \%)$ & $1(25.0 \%)$ & $0(0 \%)$ & 4 \\
\hline Oral hypoglycemic agents (OHAs) & $98(45.4 \%)$ & $77(41.6 \%)$ & $41(19.0 \%)$ & 216 \\
\hline Insulin & $11(21.6 \%)$ & $17(33.3 \%)$ & $23(45.1 \%)$ & 51 \\
\hline
\end{tabular}




\section{Number of OHAs}

One

$58(36.7 \%) \quad 55(34.8 \%) \quad 45(28.5 \%) \quad 158$

Two $64(41.3 \%) \quad 59(38.1 \%) \quad 32(20.6 \%) \quad 155$

Missing

Presence of complications

Yes

No

$108(35.8 \%) \quad 113(37.4 \%) \quad 81(20.6 \%) \quad 302$

Average Blood pressure

Controlled $(<140 / 90 \mathrm{mmHg})$

Uncontrolled $(\geq 140 / 90 \mathrm{mmHg})$

$58(37.4 \%) \quad 51(32.9 \%) \quad 46(29.7 \%) \quad 155$

\section{HIV status}

Positive

$78(36.6 \%) \quad 81(38.0 \%) \quad 54(25.4 \%) \quad 213$

Negative

$19(50.0 \%) \quad 8(21.1 \%) \quad 11(28.9 \%) \quad 38$

Don't know

$76(33.8 \%) \quad 87(38.7 \%) \quad 62(27.6 \%) \quad 225$

Anaemia

$41(39.0 \% \quad 37(35.2 \%) \quad 27(25.5 \%) \quad 105$

Moderate

$11(37.9 \%) \quad 8(27.6 \%) \quad 10(34.5 \%) \quad 29$

Mild

$17(32.1 \%) \quad 21(39.6 \%) \quad 15(28.3 \%) \quad 53$

No anaemia

$104(38.0 \%) \quad 99(36.1 \%) \quad 71(25.9 \%) \quad 274$


Table 2: Factors associated with good glycemic control among the study population

\begin{tabular}{|c|c|c|c|c|}
\hline \multirow[t]{2}{*}{ Variables } & \multicolumn{2}{|l|}{ Desirable control } & \multicolumn{2}{|c|}{ Suboptimal control } \\
\hline & $\begin{array}{l}\text { Crude OR (95\% } \\
\text { CI) }\end{array}$ & p-value & $\begin{array}{l}\text { Crude OR } \\
(95 \% \mathrm{CI})\end{array}$ & p-value \\
\hline \multicolumn{5}{|l|}{ Gender } \\
\hline Male & 1 (Ref) & & 1 (Ref) & \\
\hline Female & $1.913(1.09-3.36)$ & 0.024 & $1.46(0.84-2.53)$ & 0.177 \\
\hline \multicolumn{5}{|l|}{ Age in years } \\
\hline $21-35$ & 1 (Ref) & & 1 (Ref) & \\
\hline $36-50$ & $3.23(1.04-10.06)$ & 0.043 & $4.31(1.41-$ & 0.01 \\
\hline $51-65$ & $6.27(2.17-18.16)$ & 0.001 & $13.15)$ & $<0.001$ \\
\hline$\geq 66$ & $\begin{array}{l}12.24(3.98- \\
37.60)\end{array}$ & $<0.001$ & $\begin{array}{l}7.24(2.51- \\
20.89) \\
7.53(2.40- \\
23.61)\end{array}$ & 0.001 \\
\hline \multicolumn{5}{|l|}{ Highest level of education } \\
\hline No formal education & 1 (Ref) & & 1 (Ref) & \\
\hline Less than primary school & $0.75(0.33-1.70)$ & 0.493 & $0.76(0.32-1.80)$ & 0.53 \\
\hline Primary school completed & $0.91(0.41-2.06)$ & 0.829 & $1.46(0.64-3.32)$ & 0.37 \\
\hline Secondary school completed & $0.51(0.22-1.18)$ & 0.115 & $0.78(0.34-1.82)$ & 0.57 \\
\hline College/University completed & $0.40(0.15-1.05)$ & 0.062 & $0.57(0.21-1.49)$ & 0.25 \\
\hline Postgraduate degree & $2.13(0.22-20.73)$ & 0.514 & $\begin{array}{l}0.70(0.04- \\
11.96)\end{array}$ & 0.80 \\
\hline \multicolumn{5}{|l|}{ Marital status } \\
\hline Married/ Cohabiting & 1 (Ref) & & 1 (Ref) & \\
\hline 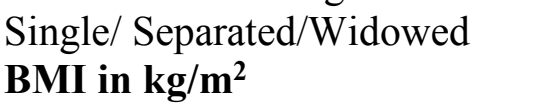 & $1.04(0.62-1.74)$ & 0.879 & $1.21(0.72-2.04)$ & 0.47 \\
\hline Underweight & 1 (Ref) & & 1 (Ref) & \\
\hline Normal weight & $1.04(0.14-8.04)$ & 0.967 & $1.56(0.13-$ & 0.723 \\
\hline Overweight & $1.86(0.25-14.15)$ & 0.547 & 18.661) & 0.409 \\
\hline Obese & $1.60(0.22-11.81)$ & 0.648 & $\begin{array}{l}2.82(0.24- \\
33.05) \\
3.57(0.31- \\
40.69)\end{array}$ & 0.306 \\
\hline \multicolumn{5}{|l|}{ Type of diabetesmellitus } \\
\hline Type 1 & 1 (Ref) & & $1(\operatorname{Ref})$ & \\
\hline Type 2 & $\begin{array}{l}12.76(2.86- \\
56.91)\end{array}$ & 0.001 & $\begin{array}{l}4.84(1.71- \\
13.71)\end{array}$ & 0.003 \\
\hline \multicolumn{5}{|l|}{ Duration of Diabetes in years } \\
\hline$<5$ & 1 (Ref) & & 1 (Ref) & \\
\hline $5-10$ & $0.47(0.25-0.91)$ & 0.02 & $0.70(0.37-1.34)$ & 0.28 \\
\hline$>10$ & $0.61(0.32-1.16)$ & 0.13 & $0.99(0.53-1.87)$ & 0.98 \\
\hline $\begin{array}{l}\text { Duration of attending block } 6 \\
\text { clinic }\end{array}$ & 1 (Ref) & & $1(\operatorname{Ref})$ & \\
\hline $\begin{array}{l}<3 \text { years } \\
\geq 3 \text { years }\end{array}$ & $1.06(0.63-1.79)$ & 0.83 & $1.83(1.08-3.10)$ & 0.024 \\
\hline $\begin{array}{l}\text { Modality of treatment of } \\
\text { diabetes }\end{array}$ & $>1000^{* *}$ & & $>1000^{* *}$ & \\
\hline Diet & $3.59(1.91-6.75)$ & $<0.001$ & $1.83(1.01-3.31)$ & 0.047 \\
\hline $\begin{array}{l}\text { Oral hypoglycemic agents } \\
\text { (OHAs) }\end{array}$ & $\begin{array}{l}0.72(0.30-1.74) \\
1 \text { (Ref) }\end{array}$ & 0.462 & $0.72(0.33-1.56)$ & 0.406 \\
\hline
\end{tabular}




\begin{tabular}{|c|c|c|c|c|}
\hline Insulin & & & & \\
\hline Both OHAs and Insulin & & & & \\
\hline Number of OHAs & & & & \\
\hline One & 1 (Ref) & & $1($ Ref) & \\
\hline Two & $1.55(0.87-2.76)$ & 0.135 & $1.51(0.84-2.70)$ & 0.167 \\
\hline Presence of complications & & & & \\
\hline Yes & 1 (Ref) & & 1 (Ref) & \\
\hline No & $1.11(0.58-2.12)$ & 0.763 & $2.82(0.91-8.72)$ & 0.349 \\
\hline Average Blood pressure & & & & \\
\hline Controlled $(<140 / 90 \mathrm{mmHg})$ & $1(\mathrm{Ref})$ & & 1 (Ref) & \\
\hline Uncontrolled $(\geq 140 / 90 \mathrm{mmHg})$ & $1.15(0.68-1.93)$ & 0.608 & $1.91(0.87-4.19)$ & 0.261 \\
\hline HIV status & & & & \\
\hline Positive & 1 (Ref) & & 1 (Ref) & \\
\hline Negative & $1.41(0.62-3.18)$ & 0.409 & $0.52(0.20-1.36)$ & 0.183 \\
\hline Don't know & $1.24(0.69-2.24)$ & 0.477 & $0.98(0.56-1.77)$ & 0.938 \\
\hline Anaemia & & & & \\
\hline Moderate & 1 (Ref) & & 1 (Ref) & \\
\hline Mild & $0.75(0.30-1.86)$ & 0.536 & $0.57(0.22-1.53)$ & 0.266 \\
\hline No anaemia & $0.77(0.36-1.65)$ & 0.507 & $1.00(0.48-2.08)$ & 0.991 \\
\hline
\end{tabular}

Poor control category is used as a reference category on the dependent variables

${ }^{* *}$ The hessian matrix is almost singular 
Table 3: Multinomial logistic regression of factors associated with glycemic control

\begin{tabular}{|c|c|c|c|c|}
\hline \multirow[t]{2}{*}{ Variables } & \multicolumn{2}{|l|}{ Desirable control } & \multicolumn{2}{|l|}{ Suboptimal control } \\
\hline & $\begin{array}{l}\text { Adjusted OR } \\
(95 \% \text { CI })\end{array}$ & p-value & $\begin{array}{l}\text { Adjusted OR } \\
(95 \% C I)\end{array}$ & p-value \\
\hline \multicolumn{5}{|l|}{ Gender } \\
\hline Male & 1 (Ref) & & 1 (Ref) & \\
\hline Female & $0.78(0.33-1.84)$ & 0.57 & $0.67(0.29-1.55)$ & 0.35 \\
\hline \multicolumn{5}{|l|}{ Age in years } \\
\hline $21-35$ & $1(\mathrm{Ref})$ & & $1($ Ref) & \\
\hline $36-50$ & $2.03(0.30-13.69)$ & 0.463 & $10.16(0.82-1.26)$ & 0.07 \\
\hline $51-65$ & $4.32(0.63-29.80)$ & 0.137 & $13.99(1.11-177.27)$ & 0.04 \\
\hline$\geq 66$ & $\begin{array}{l}11.70(1.40- \\
97.69)\end{array}$ & 0.023 & $16.31(1.10-241.70)$ & 0.04 \\
\hline \multicolumn{5}{|l|}{ Highest level of education } \\
\hline No formal education & 1 (Ref) & & 1 (Ref) & \\
\hline Primary to secondary completed & $1.44(0.44-4.74)$ & 0.552 & $1.28(0.40-4.13)$ & 0.68 \\
\hline $\begin{array}{l}\text { College/University/Postgraduate } \\
\text { completed }\end{array}$ & $1.14(0.42-3.10)$ & 0.796 & $1.08(0.40-2.96)$ & 0.88 \\
\hline \multicolumn{5}{|l|}{ Marital status } \\
\hline Married/ Cohabiting & 1 (Ref) & & 1 (Ref) & \\
\hline 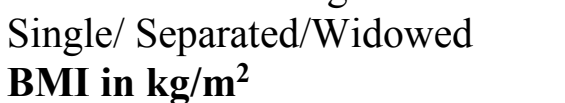 & \multicolumn{3}{|c|}{ BMI in $\mathbf{k g} / \mathrm{m}^{2}$} & 0.60 \\
\hline Underweight/Normal $(<24.99)$ & $1(\operatorname{Ref})$ & & 1 (Ref) & \\
\hline Overweight/Obese (25-) & $1.38(0.53-3.59)$ & 0.51 & $1.61(0.61-4.27)$ & 0.336 \\
\hline \multicolumn{5}{|l|}{ Duration of Diabetes in years } \\
\hline$<5$ & 1 (Ref) & & 1 (Ref) & \\
\hline $5-10$ & $0.34(0.13-0.86)$ & 0.02 & $0.39(0.15-0.98)$ & 0.04 \\
\hline$>10$ & $0.42(0.15-1.15)$ & 0.09 & $0.57(0.22-1.50)$ & 0.25 \\
\hline \multicolumn{5}{|l|}{ Duration of attending block 6} \\
\hline$<3$ years & $1.54(0.68-3.45)$ & 0.30 & $3.71(1.66-8.31)$ & 0.001 \\
\hline \multicolumn{5}{|l|}{$\geq 3$ years } \\
\hline \multicolumn{5}{|l|}{$\begin{array}{l}\text { Modality of treatment of } \\
\text { diabetes }\end{array}$} \\
\hline Diet/ & $6.41(2.28-18.00)$ & $<0.001$ & $2.96(1.03-8.47)$ & 0.043 \\
\hline \multicolumn{5}{|l|}{ Oral hypoglycemic agents } \\
\hline \multicolumn{5}{|l|}{ Insulin/ } \\
\hline \multicolumn{5}{|l|}{ Both OHAs and Insulin } \\
\hline \multicolumn{5}{|l|}{ Number of OHAs } \\
\hline One & 1 (Ref) & & 1 (Ref) & \\
\hline Two & $0.47(0.18-1.20)$ & 0.11 & $0.79(0.52-1.30)$ & 0.638 \\
\hline \multicolumn{5}{|l|}{ Presence of complications } \\
\hline Yes & 1 (Ref) & & $1(\operatorname{Ref})$ & \\
\hline No & $0.76(0.44-1.30)$ & 0.70 & $2.82(0.91-8.72)$ & 0.25 \\
\hline \multicolumn{5}{|l|}{ Average Blood pressure } \\
\hline Controlled $(<140 / 90 \mathrm{mmHg})$ & 1 (Ref) & & 1 (Ref) & \\
\hline Uncontrolled ( $\geq 140 / 90 \mathrm{mmHg})$ & $1.04(0.67-1.59)$ & 0.11 & $1.30(0.59-2.84)$ & 0.511 \\
\hline \multicolumn{5}{|l|}{ HIV status } \\
\hline Positive & $1($ Ref $)$ & & $1($ Ref $)$ & \\
\hline Negative & $4.29(1.00-18.32)$ & 0.05 & $1.08(0.23-5.09)$ & 0.922 \\
\hline
\end{tabular}




\begin{tabular}{lllll}
\hline $\begin{array}{l}\text { Don't know } \\
\text { Anaemia }\end{array}$ & $1.39(0.60-3.21)$ & 0.44 & $1.75(0.76-4.06)$ & 0.189 \\
Moderate & $1($ Ref $)$ & & $1($ Ref $)$ & \\
Mild & $0.56(0.15-2.14)$ & 0.397 & $0.50(0.13-1.93)$ & 0.317 \\
No anaemia & $0.85(0.31-2.37)$ & 0.762 & $0.83(0.30-2.25)$ & 0.706 \\
\hline
\end{tabular}

Table 4: Association between serum creatinine and glycemic control

\begin{tabular}{lllll}
\hline Variable & $\begin{array}{l}\text { Desirable } \\
\text { control }\end{array}$ & $\begin{array}{l}\text { Suboptimal } \\
\text { control }\end{array}$ & $\begin{array}{l}\text { Poor } \\
\text { control }\end{array}$ & p-value \\
\hline $\begin{array}{l}\text { Mean serum } \\
\text { creatinine in }\end{array}$ & 71.55 & 74.33 & 75.44 & 0.645 \\
umol/1 (SD) & & $(31.36)$ & $(41.62)$ & \\
\hline
\end{tabular}

